\title{
PENGARUH PELATIHAN KARYAWAN TERHADAP KINERJA KARYAWAN PADA CV CIBALUNG HAPPY LAND BOGOR
}

\author{
Nancy Yusnita \\ Dosen Tetap Fakultas Ekonomi Universitas Pakuan \\ Lecturer of Economic Faculty at Pakuan University \\ Feriza Fadhil \\ Mahasiswa Fakultas Ekonomi Universitas Pakuan \\ Student of Economic Faculty at Pakuan University
}

\begin{abstract}
ABSTRAK
Faktor yang mempengaruhi kinerja karyawan salah satunya adalah pelatihan. Pelatihan merupakan aktivitas operasional yang sangat penting dalam perusahaan. Kualitas dari karyawan dapat dikembangkan di dalam pelatihan itu sendiri. Untuk menghasilkan karyawan yang memiliki pengetahuan keahlian dan sikap mental yang sesuai dengan yang dibutuhkan perusahaan maka penyelenggaraan pelatihan merupakan suatu keharusan. Melalui adanya pelatihan akan meningkatkan kinerja karyawan sehingga dapat menunjang keberhasilan perusahaan. Metode analisis yang digunakan kualitatif deskriptif, dengan analisis yang dipakai koefisien korelasi, koefisien determinasi, analisis regresi linier sederhana, uji hipotesis korelasi dan uji hipotesis regresi. Hasil penelitian mengungkapkan fakta bahwa pelaksanaan pelatihan karyawan dan kinerja karyawan pada CV. Cibalung Happy Land Bogor cukup baik. Dasi hasil uji hipotesis terdapat hubungan yang nyata antara pelatihan karyawan dan kinerja karyawan. Hasil uji hipotesis regresi dapat disimpulkan bahwa pelatihan berpengaruh terhadap kinerja. Nilai t hitung positif berarti pengaruhnya positif, yaitu jika pelatihan naik maka kinerja akan meningkat.
\end{abstract}

Kata Kunci: pelatihan karyawan, kinerja karyawan

\begin{abstract}
The one of Factors affecting the performance of the employees is training. Training is a very important operational activities within the company. The quality of employees can be developed in the training itself. To produce employees who have the skills and knowledge appropriate mental attitude with which the company takes delivery of training is a must. Through the training will improve employee performance that can support a company's success. The analytical method used is descriptive qualitative, the analysis used is the correlation coefficient, determination coefficient, simple linear regression analysis, hypothesis testing of correlation and regression hypothesis testing. Results of the study revealed that the fact of implementation of employee training and employee performance in CV Cibalung Happy Land Bogor pretty good. The hypothesis test results is a real relationship between employee training and employee performance. Results of regression hypothesis test can be concluded that the training effect on performance. Positive $t$ value means a positive effect, namely if the training climb performance will increase.
\end{abstract}

Keywords: employee training, employee performance

\section{Pendahuluan}

Perkembangan di dalam dunia bisnis pada saat ini mengakibatkan persaingan antara perusahaan semakin kompetitif. Perusahaan perlu menerapkan suatu sistem yang tepat untuk dapat menjaga keberlangsungan kegiatan operasionalnya.
Pelatihan sering dianggap sebagai aktifitas yang paling dapat dilihat dan paling umum dari semua aktifitas kekaryawanan. Pelatihan yang baik dapat juga menunjang keberhasilan suatu perusahaan dalam mencapai tujuannya. Adanya pelatihan tersebut akan menciptakan kinerja karyawan yang 
tinggi sehingga dapat menunjang keberhasilan perusahaan.

Kinerja karyawan merupakan suatu hal yang sangat penting dalam upaya perusahaan untuk mencapai tujuan. Dengan adanya kinerja yang tinggi yang dimiliki karyawan, diharapkan tujuan perusahaan yang diinginkan dapat tercapai.

CV Cibalung Happy Land Bogor merupakan perusahaan yang bergerak di bidang wisata alam dan rekreasi yang berada di jalan Cihideung-Bogor Kp. Cibalung Ds. Cibalung. Beberapa pengamatan awal yang dilakukan di CV Cibalung Happy Land Bogor masih ditemukan beberapa fenomena yang menggambarkan masih belum optimalnya kinerja karyawan yang berada di CV Happy Land Bogor tersebut, seperti belum maksimalnya kinerja karyawan terutama dalam kerjasama untuk menyelesaikan pekerjaan, masih perlu ditingkatkannya pemahaman masing-masing karyawan dalam penguasaan keterampilan dan keahlian mengenai outbond dan agrowisata, masih banyaknya keluhan pengunjung, dan masih adanya karyawan yang belum dapat menjalankan dengan baik pembelajaran yang diperoleh selama pelatihan.

Karyawan CV Cibalung Happy Land Bogor dituntut untuk bekerja dengan baik agar memberikan rasa nyaman dan aman bagi pengunjung. Manajemen CV Cibalung Happy Land Bogor harus benar-benar dalam melaksanakan pelatihan bagi karyawannya, agar karyawan tersebut memiliki kemampuan, keahlian, pengetahuan, yang sesuai untuk menjalankan tugasnya dengan baik. Sehingga akan memberikan rasa nyaman bagi pengunjung, menjaga keselamatan pengunjung, dan meningkatkan jumlah pengunjung.
Adapun tujuan penelitian ini adalah sebagai berikut: 1. Untuk mengetahui pelatihan karyawan pada CV. Cibalung Happy Land Bogor, 2. Untuk mengetahui kinerja karyawan pada CV. Cibalung Happy Land Bogor, dan 3. Untuk mengetahui pengaruh pelatihan terhadap kinerja karyawan pada CV. Cibalung Happy Land Bogor.

\section{Metode Penelitian}

Jenis penelitian ini adalah penelitian kuantitatif dengan menggunakan uji validitas dan uji reliabillitas pada setiap variabel. Metode analisis yang digunakan adalah analisis koefisien korelasi, analisis koefisien determinasi, analisis regresi linier sederhana, uji hipotesis korelasi, dan uji hipotesis regresi.

\section{Hasil Penelitian}

3.1. Pelatihan Karyawan pada CV. Cibalung Happy Land Bogor

Hasil kuesioner yang disebarkan kepada responden, sebagai berikut:

1. Materi Pelatihan

Berdasarkan hasil perhitungan rata-rata responden mengidentifikasikan bahwa mayoritas karyawan CV. Cibalung Happy Land Bogor sangat setuju bahwa materi pelatihan yang diberikan sesuai dengan kebutuhan karyawan.

2. Metode Pelatihan

Berdasarkan hasil perhitungan rata-rata responden mengindikasikan bahwa mayoritas karyawan CV. Cibalung Happy Land Bogor sangat setuju metode pelatihan sesuai dengan materi yang disajikan.

3. Pelatih (Instruktur)

Berdasarkan hasil perhitungan rata-rata

responden 
mengindikasikan bahwa mayoritas karyawan CV. Cibalung Happy Land Bogor sangat setuju instruktur pelatihan menguasai materi dan metode yang disampaikan.

4. Peserta Pelatihan

Berdasarkan hasil perhitungan rata-rata responden mengindikasikan bahwa mayoritas karyawan CV. Cibalung Happy Land Bogor setuju peserta pelatihan siap untuk mengikuti pelatihan.

\section{Sarana Pelatihan}

Berdasarkan hasil perhitungan rata-rata responden mengindikasikan bahwa mayoritas karyawan CV. Cibalung Happy Land Bogor setuju sarana pelatihan sudah sesuai dengan standar. Nilai skor rata-rata diuji dengan sebaran nilai interval pelatihan. Berdasarkan sebaran nilai interval sebesar $52,77 \%$ dapat disimpulkan bahwa pelaksanaan pelatihan yang diterapkan di CV. Cibalung Happy Land Bogor cukup baik. Hal ini mengindikasikan bahwa materi pelatihan, metode pelatihan, instruktur pelatihan, dan sarana pelatihan telah mendukung proses pelatihan dengan baik dan sesuai dengan yang ditetapkan perusahaan.

\subsection{Kinerja Karyawan pada CV.} Cibalung Happy Land Bogor

Tanggapan responden Manager

Personalia CV. Cibalung Happy land Bogor mengenai pernyataan kinerja karyawan:

1. Kualitas Pekerjaan

Berdasarkan dari hasil perhitungan responden mengindikasikan bahwa kinerja karyawan $\mathrm{CV}$.
Cibalung Happy Land Bogor mayoritas memberikan kualitas hasil kerja sangat memuaskan.

2. Ketepatan Waktu

Berdasarkan dari hasil perhitungan responden mengindikasikan bahwa kinerja karyawan $\mathrm{CV}$. Cibalung Happy Land Bogor mayoritas dapat bekerja tepat waktu dengan sanngat memuaskan.

3. Kemampuan Kerjasama

Berdasarkan dari hasil perhitungan responden mengindikasikan bahwa kinerja karyawan $\mathrm{CV}$. Cibalung Happy Land Bogor mayoritas mampu bekerjasama dengan sangat memuaskan. Nilai skor rata-rata diuji dengan sebaran nilai interval kinerja. Berdasarkan sebaran nilai interval sebesar 56\% dapat disimpulkan bahwa penilaian kinerja karyawan yang dilakukan di CV. Cibalung Happy Land Bogor cukup baik. Hal ini menunjukan bahwa kinerja karyawan CV. Cibalung Happy Land Bogor sudah sesuai dengan yang diharapkan oleh perusahaan. Mayoritas memberikan kualitas hasil kerja cukup baik, tepat waktu dalam bekerja, dan mampu bekerjasama dengan cukup baik.

\subsection{Pengaruh Pelatihan Karyawan Terhadap Kinerja Karyawan pada CV. Cibalung Happy Land Bogor}

1. Analisis Koefisien Korelasi

Dilakukan analisis korelasi pearson untuk mengetahui keeratan hubungan antara pelatihan dengan kinerja. Interpretasi hasil dari output SPSS adalah sebagai berikut:

Output Correlations menjelaskan tentang nilai koefisien korelasi dan 
nilai signifikansi antara variabel pelatihan dengan kinerja. Dapat diketahui dari korelasi antara variabel pelatihan dengan kinerja didapat nilai koefisien sebesar 0,368, maka dapat disimpulkan bahwa hubungan antara pelatihan dengan kinerja adalah lemah.

2. Analisis Koefisien Determinasi

Hasil dari analisis tersebut menunjukkan bahwa kontribusi variabel pelatihan terhadap variabel kinerja karyawan sebesar $13,6 \%$. Sedangkan sisanya sebesar $86,4 \%$ dipengaruhi oleh faktor lain di luar pelatihan karyawan.

3. Analisis Regresi Linier Sederhana Output menjelaskan tentang nilai koefisien, nilai $\mathrm{t}$ hitung, dan signifikansi. Nilai-nilai pada output dimasukkan ke dalam persamaan regresi, yaitu $Y^{\prime}=40,639+0,313 \mathrm{X}$ arti dari persamaan regresi tersebut adalah jika perusahaan tidak memberikan pelatihan kepada karyawan maka kinerja yang dihasilkan sebesar 40,639 satuan dan jika perusahaan meningkatkan pelatihan karyawan sebesar 1 satuan maka kinerja yang dihasilkan akan meningkat sebesar 40,952 satuan.

4. Uji Hipotesis Korelasi

Uji hipotesis koefisien korelasi digunakan untuk melihat apakah hipotesis yang dibuat dapat diterima atau ditolak dan adakah hubungan ynag nyata atau tidak antara pelatihan dengan kinerja karyawan, maka dilakukan uji hipotesis koefisien korelasi. Nilai $t_{\text {hitung }}>t_{\text {tabel }}(2,311>2,0322)$ maka $\mathrm{H}_{\mathrm{o}}$ ditolak $\mathrm{H}_{\mathrm{a}}$ diterima, artinya terdapat hubungan yang nyata antara variabel $\mathrm{X}$ (Pelatihan
Karyawan) dan Variabel Y (Kinerja Karyawan).

5. Uji Hipotesis Regresi

Uji hipotesis ini untuk mengetahui apakah variabel pelatihan berpengaruh secara signifikan atau tidak terhadap kinerja. Nilai $t_{\text {hitung }}>t_{\text {tabel }}(2,310>2,032)$ maka $H_{o}$ ditolak $\mathrm{H}_{\mathrm{a}}$ diterima. Jadi dapat disimpulkan bahwa pelatihan berpengaruh terhadap kinerja. Nilai $t$ hitung positif berarti berpengaruh positif, yaitu jika pelatihan naik maka kinerja akan meningkat.

\section{Kesimpulan}

1. Pelaksanaan pelatihan yang dilakukan oleh CV. Cibalung Happy Land Bogor berdasarkan tanggapan hasil responden menunjukkan hasil yang cukup baik. Karyawan menilai bahwa materi pelatihan, metode pelatihan, instruktur pelatihan, dan sarana pelatihan telah mendukung proses pelatihan dengan baik dan sesuai dengan yang ditetapkan oleh perusahaan.

2. Penilaian kinerja karyawan secara individu CV. Cibalung Happy Land Bogor berdasarkan tanggapan hasil responden menunjukkan hasil ynag cukup baik. Hal ini mengindikasikan bahwa karyawan CV. Cibalung Happy Land Bogor mayoritas memberikan kualitas hasil kerja cukup baik, tepat waktu dalam bekerja, dan mampu bekerjasama dengan cukup baik.

3. Hasil uji hipotesis regresi diperoleh nilai $t_{\text {hitung }}>t_{\text {tabel }}$ (2,310>2,032) maka $\mathrm{H}_{\mathrm{o}}$ ditolak $\mathrm{H}_{\mathrm{a}}$ diterima. Jadi dapat disimpulkan bahwa pelatihan berpengaruh terhadap kinerja. Nilai $\mathrm{t}$ hitung 
positif berarti berpengaruh positif, yaitu jika pelatihan naik maka kinerja akan meningkat.

\section{Daftar Pustaka}

Abdullah, M Ma'ruf. 2014. Manajemen dan Evaluasi Kinerja Karyawan. Yogyakarta: ASWAJA.

Bangun, Wilson. 2012. Manajemen Sumber Daya Manusia. Jakarta: Erlangga.

Cushway Barry. 2001. Human Resource Management. New Jersey: Pearson Education Inc.

Dessler, Gary. 2005. Human Resource Managemen. New Jersey: Pearson Education Inc.

Harbani Pasolong. 2012. Metode Penelitian Administrasi Publik. Bandung: Alfabeta.

I Komang, Ardana, Mujiati, Ni Wayandan Utama, I Wayan Mudiartha. 2012. Manajemen
Sumber Daya Manusia. Yagyakarta: Graha Ilmu.

Kaswan. 2011. Pelatihan dan Pengembangan. Bandung: Alfabeta.

Mangkunegara, Anwar Prabu. 2009. Manajemen Sumber Daya Manusia dan Perusahaan. Bandung: PT Remaja Rosda Karya.

Noe, Hollenbeck, Gerhart, Wright. 2003. Human Resource Management Interntional Edition. New York: The McGraw-hill Companies, Inc.

Rachmawati, Ike Kusdyah. 2008. Manajemen Sumber Daya Manusia. Yogyakarta: Andi.

Sutrisno, Edy. 2010. Budaya Organisasi. Jakarta: Kencana Prenada Media Group.

Wayne Mondy R. 2008. Manajemen Sumber Daya Manusia Jilid 1. Jakarta: Erlangga. 